\title{
BRONZE VESSELS DISCOVERED IN THE LOCH OF LEYS.
}

. J. H. Burnett, Esq., communicated notices of various ancient bronze vessels and other curious objects recently discovered, on draining the Loch of Leys, in the parish of Banchory-Ternan, Kincardineshire, on the estate of Sir Alexander Burnett, of Crathes, Bart., who presented two of the vessels to the Society.

The operations were commenced on the Loch in 1850, and on the 20th July an ancient Millstone was found about four feet under the surface, on an artificial island, which contains the remains of extensive buildings. $\mathrm{Mr}$ Burnett notes in his diary, of $23 \mathrm{~d}$ July, "Digging at the Loch of Leys renewed. Took out two oak trees laid across the bottom of the lake; one five feet in circumference, and nine feet long; the other shorter. It is plain that the foundation of the island has been of oak and birch trees laid alternately, and flled up with earth and stones. The bark was quite fresh on the trees.

"The island is surrounded by oak piles, which now project two or three feet 
above the ground. They have evidently been driven in to protect the island from the action of the water."

There were five Kettles or cooking utensils found in digging the bottom of the lake after the water was let off, and about $2 \frac{1}{2}$ or 3 feet under the surface. The vessels are of the usual character of what it has been customary to call Roman Tripods and Camp Kettles. One of those presented to the Society is a bronze ewer, not unlike a modern coffee-pot. It measures $9 \frac{1}{2}$ inches high, and like many others of the same class exactly corresponds with vessels figured on medieval manuseripts, e. g., the Louterell Psalter of the fourteenth century. (Vetusta Monumenta, vol. vi., Plate 24, fig. 10.)

"Two of the large vessels and one small one were found at one part of the lake, and one large, and the other small one, at some distance apart. Near to one lot was found a rude boat, about nine feet long, made without nails, with the exception of two, which are in my possession. The bottom is flat and composed of one piece of oak. A small canoe was also found, but it crumbled entirely to pieces on being exposed to the air. Some coins were also found, but one of the workmen unfortunately ran off with them. The head, horms, and some bones of a red deer were also found, about four feet under the bottom of the lake. They are of immense dimensions and are preserved at Crathes.

"The lake is situated in the parish of Upper Banchory, in Banchory-Ternan, county of Kincardine; and in the ancient titles of Sir Alexander Burnett's lands, it is called the Lake of Banchory, but in later years, the Loch of Leys. Before it was drained last year it covered about 140 acres, but originally must have covered four or five times that extent of ground.

"There is no record of what the building on the island may have been. The lands were granted by Robert Bruce to an ancestor of the present family, anno 1324. But whether the lake was acquired at that time, or about 200 years later, viz., in 1529, when certain lands called 'Banchory,' \&c., were acquired from the Archbishop of St Andrews, cannot now be ascertained. It is believed that the family of Burnett succeeded the Wauchopes, who were deprived of their possessions in consequence of their opposition to Bruce; and tradition says that the latter were driven out of their castle or tower on the lake, after a severe struggle, and that the Burnetts inhabited it till the present castle of Crathes was built about 1550. But there is no sort of written evidence in support of this tradition,

"The lake is in the neighbourhood of the Roman station of Raedykes, in the parish of Fetteresso, in the direct line to Burghhead, and is also in the vicinity of two other Roman Camps, one in the parish of Drumoak, the other in the parish of Banchory-Ternan." 